\title{
The endocrinology of the brain
}

\author{
Gareth Leng \\ Centre for Discovery Brain Sciences, University of Edinburgh, Edinburgh, UK \\ Correspondence should be addressed to G Leng: Gareth.leng@ed.ac.uk
}

\begin{abstract}
The brain hosts a vast and diverse repertoire of neuropeptides, a class of signalling molecules often described as neurotransmitters. Here I argue that this description entails a catalogue of misperceptions, misperceptions that feed into a narrative in which information processing in the brain can be understood only through mapping neuronal connectivity and by studying the transmission of electrically conducted signals through chemical synapses. I argue that neuropeptide signalling in the brain involves primarily autocrine, paracrine and neurohormonal mechanisms that do not depend on synaptic connectivity and that it is not solely dependent on electrical activity but on mechanisms analogous to secretion from classical endocrine cells. As in classical endocrine systems, to understand the role of neuropeptides in the brain, we must understand not only how their release is regulated, but also how their synthesis is regulated and how the sensitivity of their targets is regulated. We must also understand the full diversity of effects of neuropeptides on those targets, including their effects on gene expression.
\end{abstract}

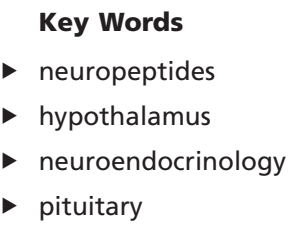

Endocrine Connections (2018) 7, R275-R285

\section{Introduction}

Endocrinology is the study of hormones, secreted by endocrine glands in one part of the body, which travel in the blood and have prolonged effects on other parts of the body - effects that are determined by tissue-specific expression of their receptors. By contrast, neuroscience is the study of the brain, and particularly of neurones that release neurotransmitters at synapses with effects tightly localised in space and time, constrained by mechanisms of rapid reuptake and degradation. The schism between neuroscience and endocrinology, between interests above the neck and below it, is reflected in differences in dominant technological and methodological approaches and in different theoretical visions. Neuroscience has been dominated by electrophysiology and the study of information transmission by mapping neuroanatomical connectivity and by studying the spiking activity of neurones and its consequences for cognition and behaviour; endocrinology by the measurement of hormones and the analysis of the mechanisms by which they are produced and the signalling mechanisms by which they act.

https://ec.bioscientifica.com

https://doi.org/10.1530/EC-18-0367

(c) 2018 The authors Published by Bioscientifica Ltd
Between these two, dangling below the brain and bathed in blood, is the pituitary gland, and dangling between neuroscience and endocrinology is neuroendocrinology, born of Geoffrey Harris' insights in the 1950s.

\section{The birth of neuroendocrinology}

In the late 1950s, it was 'well established' that in man and other animals that ovulated spontaneously, ovulation is controlled by the pituitary (1). It was commonly believed that, in each ovarian cycle, increasing levels of oestrogen triggered the secretion of gonadotropin hormones by direct actions on the pituitary. This ' $f a c t$ ' was challenged by Harris, who argued that, in inducing ovulation, oestrogen acted not on the pituitary but on the brain, where its actions resulted in the release from the hypothalamus of a substance that was carried by blood vessels to the pituitary (2). In Harris' theory, this was one 
of several 'releasing factors', each of which regulated a different pituitary hormone.

Harris and his co-workers showed that portal blood vessels in the median eminence at the base of the hypothalamus fed into a 'vascular plexus' that filled the anterior pituitary and that the direction of flow in these vessels was from the brain, not to it. He then noted that, from earlier work, transplanting the anterior pituitary gland to a different part of the body led to an irreversible loss of function and atrophy of the target tissues on which pituitary hormones were known to act. But if the anterior pituitary was removed from its normal place in the sella turcica and then replaced there or in an adjacent site, normal function often returned. Harris hypothesised that, in these cases, the portal vessels had regenerated, renewing the vascular communication between brain and pituitary (2).

To test this, Harris and Jacobsohn (3) removed the pituitary from female rats. They then grafted pituitary tissue from new-born young into the subarachnoid space below the brain, either immediately below the cut portal vessels, or to one side below the temporal lobe. Ovarian cycles returned in all rats with transplants below the cut portal vessels, but when the transplants were below the temporal lobe, the ovaries and reproductive tracts atrophied and ovarian cycles ceased. In both cases, the transplants were re-vascularised - in the first case by portal vessels, in the second case by blood vessels of a different part of the brain.

But the path to acceptance of Harris' theory was not yet clear. His theory blurred the conventionally accepted distinction between neurones and endocrine cells, and it postulated the existence of 'releasing factors' whose identification seemed beyond experimental reach. It engaged the opposition of Sir Solly Zuckerman (4). Zuckerman, as described by Lord Dainton, '...was unique. No scientist this century can match him in the timespan and weight of his influence on governments in peace or war' (5).

Zuckerman, who had founded his career on studies of the menstrual cycle in primates, recognised that Harris' theory would be disproved if any animal could be shown to have ovulated in the absence of portal vessels. In sixteen female ferrets, Thomson and Zuckerman (6) cut the neural stalk, and their case rested on results from two of them, two that had come into heat in response to artificial light even though, from their histological evidence, all connections between brain and pituitary had been eliminated.

But Harris suspected that the portal blood vessels had regenerated in these ferrets, so he and Donovan
(7) set about their own experiments on ferrets. In their key experiments, after cutting the stalk, they inserted a paper plate between the stalk and the pituitary to prevent revascularisation of the pituitary by the portal vessels. In all ferrets where the plate had been inserted effectively, there was no revascularisation and no ovulation. They thus concluded that the method of stalk sectioning and the histological techniques used by Thomson and Zuckerman were inadequate.

In 1954, Harris and Zuckerman presented their discrepant findings at a Conference in London. As later recounted by Reichlin (8), 'Harris won the debate, then, and in posterity'. Harris won, not just because his evidence was more convincing, but because he could explain something that Zuckerman could not. Zuckerman's two ferrets had come into heat in response to light - hence the pituitaries had responded to signals from the retina despite what Zuckerman had claimed to be a complete separation of the pituitary from either nerves or blood vessels. For this, Zuckerman had no credible explanation.

Zuckerman did not concede, but was still maintaining his position in 1978 (Zuckerman 1978), a year after Schally and Guillemin had been awarded the Nobel Prize for their identification of some of the releasing factors that Harris had postulated. To understand Zuckerman's resistance, we might recognise the threat that Harris' theory posed to the community of reproductive endocrinologists among which Zuckerman was a pre-eminent authority. Harris, in placing the brain as the controller of reproduction, was shifting the responsibility for extending our understanding from endocrinologists to neuroscientists to a different community, one already equipped with the expertise and technical methodologies that this change in focus demanded.

But neuroscientists, by and large, were disinclined to take up this challenge, disparaging the hypothalamus as the remnants of the 'lizard brain', and they left it to a new community of neuroendocrinologists. Harris himself set about identifying the releasing factor for gonadotropins, and came close to doing so $(9,10)$, though ultimately the prize - and the Nobel Prize that accompanied it - went to Schally and Guillemin, whose labs were resourced at a far greater level. Nevertheless, the catalogue of Harris' research reads like a road map for neuroendocrinology (2). He (with George Fink) pioneered the collection of portal blood for assays of releasing factors (11), introduced a method of remote electrical stimulation of the hypothalamus in conscious behaving animals (12) and addressed the issue of stimulus-secretion coupling in oxytocin release, a key step that became important in understanding the

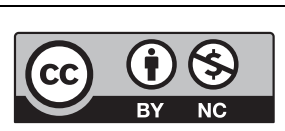

This work is licensed under a Creative Commons Attribution-NonCommercial 4.0 International License. 
significance of pulsatile hormone secretion (13). In these and many other ways, he carved out a distinctive identity for neuroendocrinology.

Barricades between endocrinologists and neuroscientists remained, and these barricades were manned by definitions. For endocrinologists, the classical definition of a 'hormone' was that given by Starling (14): 'Each specific hormone is manufactured by a group of cells and turned into the blood, in which it travels to all parts of the body, but excites definite reactions in one or a limited number of distant organs.' For neuroscientists, on the other hand, 'neurotransmitters' were expected to satisfy three criteria: (i) that they were present at synapses within the presynaptic neurones, (ii) that they were released in a $\mathrm{Ca}^{2+}$-dependent manner upon depolarization of those presynaptic neurones and (iii) that they acted on specific receptors present on the postsynaptic neurone (15).

Neither endocrinologists nor neuroscientists were rigidly bound by these definitions. For endocrinologists, Starling's definition encompassed the classical peptide and monoamine hormones well, but no complaint was made by its extension to steroid hormones, which pass cell membranes freely and can reach any targets in the body by diffusion through extravascular fluid. Nor was there objection to classing as hormones many agents that act within tissues, such as prostaglandins within the uterus, or oestrogens within the ovary, or the new host of 'local' hormones in many tissues. For neuroscientists, the definition of a neurotransmitter encompassed the classical neurotransmitters, packaged in synaptic vesicles whose release by exocytosis is tightly coupled to action potentials, but they came to concede that neurotransmitter release at synapses can 'spill over' to act at extrasynaptic receptors $(16,17,18,19,20)$.

\section{Neuropeptides}

Following the discovery of the releasing factors and their identification as mainly peptides, came the recognition that the class of 'neuropeptides' extended far beyond the class of releasing factors. They include, on current reckoning, more than 300 different peptides expressed in various combinations in distinct subpopulations of neurones throughout the brain (21). The brain had classically been assumed to be stocked with essentially homogeneous neurones that acquire functional specificity mainly through their patterns of hard-wired connections and which shared a common language of spiking activity. Now, it seemed to comprise a vast multitude of distinct neuronal types that spoke in multiple languages.
However willing neuroscientists might have been to acknowledge peptides as an additional (though minor and supplementary) class of neurotransmitters, the facts resolutely refused to conform to this notion. As I have argued elsewhere (22), the idea that neuropeptides in the brain are neurotransmitters 'is to a first approximation, a lie', at least if we retain anything of the criteria for a neurotransmitter given above.

First to be dismissed must be the misperception that neuropeptides are released at synapses within the brain. Many neurones produce both peptides and one or more neurotransmitters, and both are packaged in vesicles, but not in the same vesicles (23). Conventional neurotransmitters are packaged in small synaptic vesicles that are specifically localised to synapses. Peptides are packaged in large dense-cored vesicles that are typically distributed throughout the cytoplasm of a neurone, and since for most neurones the dendrites comprise about $85 \%$ of the cell volume, it is in this compartment that large dense-cored vesicles are often mainly found. Synaptic vesicles can only be released at specialised sites in the presynaptic membrane, but large dense-cored vesicles can apparently be released from the soma, dendrites, axonal varicosities and even undilated axons - the main requirement appears to be that they must be close to the plasma membrane to be releasable $(24,25,26,27$, $28,29,30,31)$.

Some large dense-cored vesicles are present in synapses, though not in particular abundance, and generally not close to the synaptic release site, and whether any are ever released into the synaptic cleft is questionable. Synaptic vesicles typically contain between 1000 and 5000 molecules of transmitter, and about one such vesicle is released when an action potential invades a synaptic ending. A typical synaptic cleft has an area of $\sim 1 \mu \mathrm{m}^{2}$, and a diameter of $\sim 50 \mathrm{~nm}$. If 1000 molecules are released into this, they will achieve a concentration of $\sim 0.3 \mathrm{mM}$, consistent with measures of quantal acetylcholine release at the neuromuscular junction, and amply enough to activate the low affinity receptors at which conventional neurotransmitters act (32). However, the vesicles in which peptides are packaged carry a much larger cargo. They typically contain not only the active peptide, but the entire peptide precursor. In the case of oxytocin and vasopressin, the precursors have a molecular weight of about 23,000; each vesicle contains about 85,000 of these molecules at a density so great that the contents are in crystalloid form $(33,34)$, which gives these vesicles their dense-cored appearance under the electron microscope. The release of just one of these vesicles into a synaptic cleft,

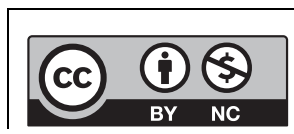

This work is licensed under a Creative Commons Attribution-NonCommercial 4.0 International License. 
if confined there, would yield a peptide concentration in the high molar range. As the receptors through which peptides act have affinities in the nanomolar range, such concentrations would not merely be massively in excess for any specific receptors present, but would also act extensively at other peptide receptors present there.

Second, is the misperception that peptide release is tightly governed by electrical activity. In the rat, about 9000 vasopressin cells project to the posterior pituitary. Each of their axons there contains about 2000 release sites (nerve terminals and swellings), each typically containing a few hundred vesicles - about 15 billion vesicles in all, with a total content of about $2 \mu \mathrm{g}$ of vasopressin (35). Ludwig and Leng estimated how often these vesicles must be secreted to achieve a basal plasma concentration of vasopressin (about $1 \mathrm{pg} / \mathrm{mL}$ ) given a half-life of $2 \mathrm{~min}$ and a volume of distribution of vasopressin of $60 \mathrm{~mL}$ (i.e. the plasma volume and total extracellular fluid volume). These imply that about 2500 vesicles/s are secreted in basal conditions (36). This calculation was based on deliberately conservative assumptions and is likely to be an overestimate; the pituitary store would be sufficient to maintain this level of secretion for only about 6 days without replenishment and for only a few hours in conditions of sustained demand, when the plasma vasopressin concentration is ten-fold higher. The actual distribution volume as inferred experimentally is about $20 \mathrm{~mL}$ in a rat, the plasma half-life is by many estimates, longer than $2 \mathrm{~min}$, and to infer the rate of clearance from this requires modelling the exchange between plasma and extravascular fluid, as vasopressin is cleared from the plasma compartment alone by passage through the kidneys and liver (37). More realistic assumptions imply a basal secretion rate of closer to 800 vesicles/s or about one vesicle every $10 \mathrm{~s}$ from each cell. After 2 days of dehydration, when vasopressin concentrations in the plasma are ten-fold higher, vasopressin cells fire action potentials (spikes) in long bursts at 6-8 spikes/s separated by silences, and each cell is secreting about 1-2 vesicles/s. In these conditions, at any single release site in the axonal endings of any one vasopressin cell, one vesicle is secreted, on average, for every 5000 spikes or so - about once every $15 \mathrm{~min}$ (22). This secretion is dependent on spike activity, but the very low probability of release at any given site implies that release is a highly stochastic process.

Third is the misconception that peptide release in the brain is governed only by electrical activity. Most of the vesicles that oxytocin cells hold within the brain are located in their long and voluminous dendrites. These are not normally releasable by electrical activity, but are constrained by an intracellular scaffold of filamentous actin to be far from the voltage-gated channels which are activated by the spikes that these dendrites conduct. However, some peptides trigger oxytocin release from these dendrites by mobilising intracellular $\mathrm{Ca}^{2+}$ stores from the rough endoplasmic reticulum that permeates the dendrites $(31,38,39)$ - and some, like $\alpha$-MSH, stimulate dendritic release even while inhibiting spiking activity (40). This is not to say that spike activity never releases dendritic oxytocin - some peptide signals can trigger a reorganisation of the filamentous actin to deliver vesicles close to the plasma membrane where they can be released in response to voltage-gated $\mathrm{Ca}^{2+}$ entry (41). This mechanism - 'priming' - underlies a change in the functional connectivity between oxytocin neurones, through autocrine and paracrine actions that bind the functional activity of oxytocin cells together. In lactation, this supports their ability to generate synchronous bursts in response to suckling, leading to the pulsatile secretion that is essential for the milk-ejection reflex (42).

Fourth is the misconception that communication between neurones requires physical proximity between them. There is often a striking mismatch between the density of receptors in any given brain region and the density of peptide-containing fibres in that region (43, 44). Much is often made of the sparse peptide-containing fibres that occasionally wend their way through regions of abundant receptor expression, and these may deliver a functionally important peptide signal, as in the case of oxytocin in the amygdala (45). But even the CSF contains oxytocin concentrations that, if present in peripheral blood, would be sufficient to activate peripheral target organs. Some brain regions distant from the sites of oxytocin synthesis contain dense plexuses of oxytocincontaining fibres, and oxytocin release from these axonal varicosities will have an important 'local' action (46) - local to the region, rather than to directly adjacent neurones. Even then we should be cautious, for every peptide-containing neurone also makes a conventional neurotransmitter, and these may often be the primary messenger of such fibres; oxytocin neurones express the vesicle glutamate transporter VGLUT2 (47), and glutamate thus appears to be a neurotransmitter used at their central synaptic projections $(45,48)$.

Oxytocin and vasopressin might be exceptional in the size of their vesicles. Many dense-cored vesicles in the CNS are smaller than these, with a volume only about $1 / 8$ that of the typical oxytocin or vasopressin-containing vesicles and a correspondingly lower expected content. Thus, van den Pol (49) favours a local diffusion hypothesis, that, 
given the low frequency of dense core vesicles in most CNS axons and because of the hours needed to replenish released peptides by synthesis and transport from the cell body, neuropeptides released by most neurons must act relatively locally on cells near the release site. However, any one neurone has a great many potential release sites, including all its axonal varicosities, each with a very low probability of release, thus, the potential targets of peptide release even from a single peptidergic neurone will be very widely scattered and widely distributed neurones will be exposed to secreted peptide in a sparse and highly stochastic fashion. When a brain region is permeated by many axons from a population of peptide-producing cells, it seems likely that such a projection will deliver a hormone-like signal to that region. How far such a signal will reach is hard to predict.

A striking demonstration of remote actions of neuropeptides comes from studies of the suprachiasmatic nucleus. Lesions of this nucleus in hamsters disrupt the circadian rhythms of behaviour that persist in constant darkness. In lesioned hamsters, circadian rhythmicity can be restored by transplanting fragments of neonatal suprachiasmatic nucleus into the third ventricle - and, remarkably, can do so even if those fragments are encapsulated in a membrane that allows substances to diffuse freely across the membrane but which permits no penetration of nerve fibres from the transplant to the host tissue (50).

Fifth, to be qualified rather than dismissed, is the notion that neuropeptides are neuromodulators, in the sense that they affect neuronal excitability, thereby altering the responses of neurones to neurotransmitters. Many neuropeptides affect gene expression in their targets: canonical examples include the effects of gonadotrophin-releasing hormone on pituitary expression of gonadotrophins $(51,52)$, the effects of thyrotropinreleasing hormone on thyroid-stimulating hormone expression (53), and the effects of growth-hormonereleasing hormone on growth hormone expression (54). Certainly many peptides do influence neuronal excitability, but as mentioned, some can alter functional connectivity by priming peptide release from dendrites.

For example, the splanchnic nerve terminals that innervate the adrenal medulla release PACAP (pituitary adenylate cyclase-activating polypeptide) and acetylcholine. Both regulate catecholamine release from chromaffin cells, but PACAP is released only at high frequencies, using secretory mechanisms different from those evoked by acetylcholine. During prolonged stress, PACAP maintains catecholamine synthesis via induction of tyrosine hydroxylase and PNMT (phenylethanolamine $\mathrm{N}$-methyltransferase), and it enhances the transcription of other secreted molecules found in chromaffin cells. In the words of Smith and Eiden: 'PACAP thus mediates chromaffin cell plasticity via a functional encoding of experience' (55).

Some neuropeptides regulate local blood flow (56), some, like oxytocin may regulate glial cell morphology (57) and leptin $(58,59)$ and CRH (60) have been proposed to modulate synaptogenesis. The predominant attention given to electrophysiological actions of neuropeptides reflects the relative ease with which these can be determined by in vitro electrophysiology, and the assumption of many neuroscientists that neuropeptides are mere adjuncts to the serious business of information transfer that is conducted by neurotransmitters.

Finally, again to be qualified or at least questioned is the notion that the roles of neuropeptides in the brain are exercised purely through activity-dependent regulation of their release. Three points should be made. (i) The level of mRNA expression for peptides in specific neuronal populations varies in different physiological states. (ii) The amount of peptide released by a given stimulus is proportional to the amount available for release, which varies with the rates of synthesis and depletion. (iii) The actions of a neuropeptide depend on the level of expression of specific receptors, which varies in different physiological conditions. These points are considered in turn below.

\section{Regulation of mRNA expression}

One of the earliest and most striking examples of this comes from studies of the effects of chronic stress on the parvocellular neurones in the paraventricular nucleus of the hypothalamus that regulate the secretion of ACTH. These neurones normally regulate ACTH secretion via release of corticotrophin releasing hormone $(\mathrm{CRH})$, but after chronic stress their expression of $\mathrm{CRH}$ is diminished while that of vasopressin, in the same neurones, is markedly enhanced. Thus the peptidergic phenotype of these neurones is plastic - what were 'CRH neurones' become 'vasopressin neurones' with marked consequences for the regulation of the stress axis (61). No less striking is the recent recognition of similar plasticity in the tuberoinfundibular dopamine neurones that regulate prolactin secretion. In lactation, these cease to release dopamine but instead release a peptide - leu enkephalin, and this change supports the stimulation of prolactin secretion in lactation (62).

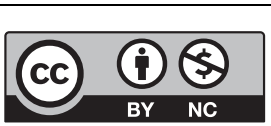

This work is licensed under a Creative Commons Attribution-NonCommercial 4.0 International License. 


\section{Regulation of receptor expression}

The role of a peptide messenger may be exercised through activity-dependent regulation of its release, or by regulating its synthesis, or its availability for release or the sensitivity of its targets. One classic example of the last of these is the importance of changes in oxytocin receptor expression in the uterus for parturition. In all mammals, oxytocin secretion is increased during parturition, and this acts on a uterus prepared by a massive increase in oxytocin receptor expression $(63,64)$. In rats, what is secreted from pituitary is conveyed to its targets in a plasma volume of about $7.5 \mathrm{~mL}$; in humans the pituitary is about 40 times larger than that of a rat, and the oxytocin content is proportionately greater. However, what is secreted in a human is conveyed in a plasma volume of $3-4 \mathrm{~L}$, at least 400 times larger than in a rat, and the half-life of oxytocin in rat and human are similar. Accordingly circulating concentrations of oxytocin are much lower in man than in small mammals (65), and the importance of the level of receptor expression in target tissues is correspondingly greater. Indeed, the increase in the sensitivity of the human uterus to oxytocin at term pregnancy is so great that it has been questioned whether any increase in the level of oxytocin at all is involved in human parturition before the third stage of labour (64).

Among the best-known behavioural functions of peptides are those of vasopressin and oxytocin on various facets of 'social' behaviour. A feature of these is how great are the species differences in these behaviours; the paradigmatic exemplars are the prairie voles, which make enduring partner bonds after mating and display biparental nurturing behaviours, and closely related species such as meadow voles which are promiscuous and asocial. These behaviours critically depend on the release within the brain of oxytocin and vasopressin, but the species differences do not apparently reflect any differences in the regulation of this release, but on differences in the sites and extent of receptor expression in the brain $(66,67)$.

\section{Stimulus-secretion coupling}

The amount of peptide secreted from neurones in response to electrical depolarisation depends on the pattern of stimulation $(37,55,68,69)$, on the number of vesicles available for release (70), and their precise location (24). The nerve endings of the axons that fill the posterior pituitary contain a 'readily-releasable pool' of vesicles that is refilled from reserve stores as it is depleted, and the cycle of local depletion and repletion results in complex nonlinearities in stimulus-secretion coupling $(37,69)$. After a period of water deprivation, the gland content is severely depleted, and in these conditions electrical stimulation of the gland releases oxytocin and vasopressin in direct proportion to the gland content (70).

When a synaptic vesicle containing a conventional neurotransmitter releases its contents, there is an abundant stock of vesicles available to re-supply the releasable pool, and re-uptake mechanisms recover neurotransmitter from the extracellular fluid to refill the empty vesicle and make it available for rapid re-use. By contrast, large-dense cored vesicles cannot be re-used, they must be replaced by newly synthesised vesicles. Thus, any acute activation of peptide secretion entails a cycle of depletion and repletion. Any marked increase in the rate of secretion must be compensated for by an increase in the rate of peptide synthesis and vesicle production, and the new vesicles must be transported from the cell body to the release sites - a process that can take several hours. This phenomenon will impose a temporal pattern on peptide secretion from neurones even if the signal for that secretion is unchanging.

But the availability of peptide stores is not the only factor that determines how much is secreted in response to a stimulus. As mentioned, priming of peptide stores can alter stimulus-secretion coupling in dendrites. At nerve terminals, other factors can do so. Oxytocin neurones, for example, co-express dynorphin, which acts on kappa-opioid receptors at their nerve terminals as an inhibitory feedback regulator of stimulussecretion coupling. In pregnancy, the expression of dynorphin is upregulated, and the enhanced negative feedback contributes to a progressive accumulation of oxytocin stores in the pituitary in preparation for parturition - the gland content increases by about a third without any apparent increase in the level of oxytocin mRNA expression (63).

In $\beta$-pancreatic cells, insulin secretion in response to glucose is elicited by an increase in intracellular $\left(\mathrm{Ca}^{2+}\right)$. This 'triggering' pathway depends on the suppression of $\mathrm{K}_{\text {ATP }}$ channels in the plasma membrane (71). But after the first phase of insulin secretion, a metabolic amplifying pathway is engaged which depends on the initial triggering signal but is independent of $\mathrm{K}_{\mathrm{ATP}}$ channels and involves cAMP signalling. This pathway enhances the sensitivity of the insulin-containing secretory vesicles to a given $\mathrm{Ca}^{2+}$ influx, and it can be engaged by peptide signals such as GLP-1 and GIP from gastrointestinal endocrine cells (72).

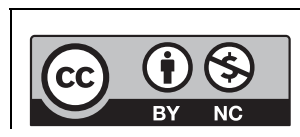
This work is licensed under a Creative Commons
Attribution-NonCommercial 4.0 International License. 


\section{Three modes of action of neuropeptides}

When considering the actions on neurones of neuropeptides released from neurones in the brain, we can recognise three common modes of action. Neuropeptides act as autoregulators of neuronal activity, as paracrine regulators of aggregated populations of neurones, and as neurohormonal regulators of distant populations of neurones.

\section{Autocrine regulation}

Commonly, neurones express autoreceptors for the peptides that they release. As discussed above, in the case of oxytocin cells, activity-dependent release of dynorphin, a peptide co-packaged with oxytocin in neurosecretory vesicles but in very much lower abundance, is a negative feedback regulator of secretion from nerve terminals in the pituitary. Magnocellular vasopressin cells also express dynorphin, co-packaged in vasopressincontaining vesicles. For these cells, dynorphin is again an autoregulator, but in this case of electrical activity - in vasopressin cells, sparse, activity-dependent release of dynorphin from the soma and dendrites has a critical role in sculpting the phasic pattern of electrical activity (73).

\section{Paracrine regulation}

Oxytocin cells also express oxytocin receptors and vasopressin cells also express vasopressin receptors, but in both cases their functional activity is quite elusive; because the receptors are internalised after ligand binding, and because there is a high concentration of these peptides in the extracellular space around the magnocellular cells, at any given time there are normally few free receptors available for binding on the cell surface. For oxytocin cells therefore these receptors are functionally effective only when very large amounts of oxytocin are released. During lactation, dendritic oxytocin release in response to suckling binds the population of oxytocin cells together, supporting their ability to generate synchronous bursts of activity (42). This can be considered as an example of positive feedback, but negative feedbacks can also bind a population together. In magnocellular vasopressin cells, dendritic vasopressin release is an inhibitor of neuronal activity - it acts as a 'population signal' allowing each cell to be aware of the level of activity amongst the whole population, and this feedback serves to equalise the average level of activity in the population, spreading the load of activity equitably $(22,74)$.

\section{Neurohormonal actions}

Neuropeptides in the brain are not generally scoured from the extracellular space by uptake mechanisms, and enzymatic degradation is relatively slow. They travel within the brain not by diffusion, but by the continuous flow of extracellular fluid, ending up in the CSF from which they are ultimately cleared. How much reaches the CSF varies considerably. Oxytocin and vasopressin are degraded within brain tissue by specific aminopeptidases, notably the membranebound enzyme PLAP (75). Oxytocin and vasopressin are released in equimolar amounts with their respective neurophysins, which are large fragments of their precursor molecules, and the neurophysins are not enzymatically degraded within the brain. By comparing the concentrations of neurophysins in CSF with those of oxytocin and vasopressin, and given the rate of clearance from CSF, we can deduce that only about $5 \%$ of the oxytocin and vasopressin that is released within the brain actually reaches the CSF (36). Yet their concentrations in CSF are still about ten-fold higher than the basal concentrations in plasma, and at levels that, when present in plasma, are amply sufficient to exert physiological effects. Peptide concentrations must vary considerably in different brain regions, as the result of differential degradation, the inhomogeneous flow of extracellular fluid and the variations in levels of local release. Neurohormonal signalling in brain is not homogeneous and indiscriminate. Nevertheless, such signalling reflects not a rapid and specific system of communication from neurone to neurone, but a prolonged communication between one population of cells and another - the difference between a 'whispered secret' and a 'public announcement' (36).

The potential impact of such neurohormonal signals might be glimpsed from studies in simple organisms such as Drosophila (76) and C. elegans (77). It seems that the connectome - the wiring diagram of connectivity amongst the 302 neurones of C. elegans - allows multiple potential behaviours for any given neuronal network. Which of these behaviours is expressed in a given circuit at a particular time depends on what Cornelia Bargmann called 'the dark energy of the nervous system.' The C. elegans genome encodes over 200 peptides, and these, she argues, along with biogenic amines such as serotonin and dopamine, sculpt the functional connectivity between neurones - defining which of the set of latent circuits in a neuronal network is engaged at a given time (77).

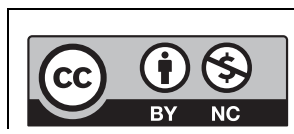

This work is licensed under a Creative Commons Attribution-NonCommercial 4.0 International License. 


\section{Reflections}

The original schism between endocrinology and neuroscience was bolstered by the apparently separate embryological origins of neurones and endocrine cells. However if we look to contemporary understanding of the molecular determinants of cell fate and to comparative genomics, we see a different story $(78,79)$. In Urbilateria, the marine organism proposed to be the last common ancestor of vertebrates, flies, and worms, cells that secreted a peptide ancestor of vasopressin and oxytocin combined properties that we have thought of as separate properties of endocrine cells and neurones. They used diverse signalling mechanisms, made both neurotransmitters and peptides, and had a wide range of specialized senses, linking feeding, reproduction and internal homeostasis to environmental conditions (80).

Given the many commonalities between, for example, $\beta$-pancreatic cells or any of the pituitary cell types and neurones, it seems clear that if these cells were embedded in the brain we would not hesitate to call them neurones. Yet although information flows in both directions between the brain and endocrine glands, we still cleave to a hierarchical view in which the brain, and the higher centres of the brain in particular, are credited with particular cognitive agency, as though neurones were clever in ways that endocrine cells are not.

We can extend this argument to encompass all endocrine cells in the body. For example, the adipocytes that store our fat not only sense the environment in which they reside, they communicate bidirectionally with other endocrine cells in the pancreas $(81,82)$ and elsewhere, express intrinsic circadian rhythmicity (83), and are innervated by neurones $(84,85)$. Through the actions of their product leptin on the brain, they not only regulate appetite by their effects on diverse populations of peptidergic neurones $(86,87)$, but also modulate energy expenditure (88) and food reward (89, 90). As I have argued elsewhere, 'from the perspective of an adipocyte (...) the brain is just something that follows its instructions to keep it supplied with lipid' (22).

There are two distinct ways to conceive of intelligence. We can conceive it as the ability of a cell to sense both the external environment and its internal state combined with the ability to respond adaptively to changes in the external environment. This would be to follow the sense in which Barbara McClintock, in her Nobel Prize lecture wrote 'a goal for the future would be to determine the extent of knowledge the cell has of itself and how it uses that knowledge in a 'thoughtful' manner when challenged' (91). Or we can conceive it as an emergent phenomenon, a property specific to highly complex multicellular systems that embraces the abilities to learn from past experience, to anticipate future challenges and to select from a range of possible strategies one that will appropriately meet those challenges. Intelligence in the latter sense is embodied not in a discrete location but in the whole complex network. In neither sense can we accord neurones greater cognitive capacity than, say, adipocytes.

Hierarchical metaphors of the organisation of brain and body have run their course. It is time to abandon them, and abandon too the conceit that will understand the brain through studies of neuronal connectivity and electrical activity alone. New technological advances, such as optogenetics and chemogenetics, have given unprecedented opportunities for understanding the role of electrical activity in information processing in the brain, but we are desperately in need of comparable advances in studying the functional regulation of neuropeptide release in the brain and its behavioral and physiological consequences.

It is time for endocrinologists to claim the brain as one of their own, and take up the challenge of understanding the hormones of the brain. At present, we have the technical ability to measure only oxytocin and vasopressin release by radioimmunoassay in brain areas in a functional context, and only with a relatively poor spatial and temporal resolution. Nanoflow liquid chromatographymass spectrometry offers a potentially powerful alternative to immunoassay for peptide detection because of its high sensitivity and specificity, and a recent paper has used this to measure opioid peptide release in discrete brain areas using microdialysis in fractions collected at 15-min intervals (92). This is clearly a step forward, but temporal resolution remains a challenge. Important advances have recently been made in the ability to measure the release of some neurotransmitters with high spatial and temporal resolution through the use of genetically encoded fluorescent sensors $(93,94)$. It seems possible that similar approaches may yet provide the ability to measure neuropeptide release with similar precision, but there are considerable technical barriers (95).

While chemogenetic approaches directly target G-protein-coupled receptors, optogenetic approaches have mainly been used to activate or inhibit neurones through regulation of ion channels $(45,96)$. However, optogenetic tools have also been developed to target intracellular signalling cascades (97). Thus, both optogenetic and chemogenetic approaches should be capable of being adapted to target the non-spike-dependent pathways that

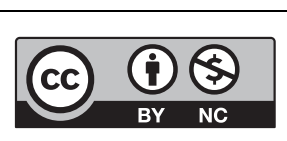

This work is licensed under a Creative Commons Attribution-NonCommercial 4.0 International License. 
regulate peptide release - if the problems with measuring this release on an appropriate timescale can be overcome.

\section{Declaration of interest}

The author declares that there is no conflict of interest that could be perceived as prejudicing the impartiality of this review.

\section{Funding}

Research in the author's lab is funded by the European Union's Seventh Framework Programme for Research, Technological Development, and Demonstration under Grant number 607310 (Nudge-lt.) and by the BBSRC (BB/S000224/1).

\section{References}

1 Hisaw FL. Development of the Graafian follicle and ovulation. Physiological Reviews 194727 95-119. (https://doi.org/10.1152/ physrev.1947.27.1.95)

2 Harris GW.. Neural control of the pituitary gland. In Monographs of the Physiological Society, p 298. London: E. Arnold, 1955.

3 Harris GW \& Jacobsohn D.. Functional grafts of the anterior pituitary gland. Proceedings of the Royal Society of London: Series B, Biological Sciences 1952139 263-276. (https://doi.org/10.1098/rspb.1952.0011)

4 Coen CW. 60 YEARS OF NEUROENDOCRINOLOGY: Celebrating the brain's other output-input system and the monograph that defined neuroendocrinology. Journal of Endocrinology 2015226 E3-E6. (https://doi.org/10.1530/JOE-15-0251)

5 Dainton L. Zuckerman, Solly May 30, 1904 April 1, 1993. Proceedings of the American Philosophical Society 1995139 211-217.

6 Thomson AP \& Zuckerman S. The effect of pituitary-stalk section on light-induced oestrus in ferrets. Proceedings of the Royal Society of London: Series B, Biological Sciences 1954142 437-451. (https://doi. org/10.1098/rspb.1954.0035)

7 Donovan BT \& Harris GW. The effect of pituitary stalk section on light-induced oestrus in the ferret. Journal of Physiology 1956131 102-114. (https://doi.org/10.1113/jphysiol.1956.sp005447)

8 Reichlin S. 60 YEARS OF NEUROENDOCRINOLOGY: MEMOIR: working in the 'Huts' with the professor: the first Maudsley years. Journal of Endocrinology 2015226 E7-E11. (https://doi.org/10.1530/ JOE-15-0034)

9 Vogt ML. Geoffrey Wingfield Harris, 1913-1971. Biographical Memoirs of Fellows of the Royal Society 197218 309-329. (https://doi. org/10.1098/rsbm.1972.0010)

10 Naftolin F, Harris GW \& Bobrow M. Effect of purified luteinizing hormone releasing factor on normal and hypogonadotrophic anosmic men. Nature 1971232 496-497. (https://doi. org/10.1038/232496a0)

11 Fink G. 60 YEARS OF NEUROENDOCRINOLOGY: MEMOIR: Harris' neuroendocrine revolution: of portal vessels and self-priming. Journal of Endocrinology 2015226 T13-T24. (https://doi.org/10.1530/JOE-150130)

12 Harris GW \& Woods JW. Electrical stimulation of the hypothalamus and thyroid activity. Nature 1956178 80-81. (https://doi. org/10.1038/178080a0)

13 Leng G., Pineda R, Sabatier N \& Ludwig M. 60 YEARS OF NEUROENDOCRINOLOGY: The posterior pituitary, from Geoffrey Harris to our present understanding. Journal of Endocrinology 2015 226 T173-T185. (https://doi.org/10.1530/JOE-15-0087)

14 Starling EH. THE WISDOM OF THE BODY: The Harveian Oration, delivered before The Royal College of Physicians of London on St. Luke's Day, 1923. BMJ 19232 685-690. (https://doi.org/10.1136/ bmj.2.3277.685)
15 Purves D \& Williams SM. Neuroscience, 2nd ed., p xviii, 681, 16, 3, 25. Sunderland, MA, USA.: Sinauer Associates, 2001.

16 Hirasawa H, Contini M \& Raviola E. Extrasynaptic release of GABA and dopamine by retinal dopaminergic neurons. Philosophical Transactions of the Royal Society of London: Series B, Biological Sciences 2015370 20140186. (https://doi.org/10.1098/rstb.2014.0186)

17 Rice ME, Patel JC, \& Cragg SJ. Dopamine release in the basal ganglia. Neuroscience 2011198 112-137. (https://doi.org/10.1016/j. neuroscience.2011.08.066)

18 Fuxe K, Agnati LF, Marcoli M, \& Borroto-Escuela DO. Volume transmission in central dopamine and noradrenaline neurons and its astroglial targets. Neurochem Research 201540 2600-2614. (https:// doi.org/10.1007/s11064-015-1574-5)

19 Courtney NA \& Ford CP. The timing of dopamine- and noradrenaline-mediated transmission reflects underlying differences in the extent of spillover and pooling. Journal of Neuroscience 201434 7645-7656. (https://doi.org/10.1523/JNEUROSCI.0166-14.2014)

20 Lendvai B \& Vizi ES. Nonsynaptic chemical transmission through nicotinic acetylcholine receptors. Physiological Reviews $2008 \mathbf{8 8}$ 333-349. (https://doi.org/10.1152/physrev.00040.2006)

21 Wang Y, Wang M, Yin S, Jang R, Wang J, Xue Z \& Xu T. NeuroPep: a comprehensive resource of neuropeptides. Database 20152015 bav038. (https://doi.org/10.1093/database/bav038)

22 Leng G. The Heart of the Brain: The Hypothalamus and Its Hormones, p 280. Cambridge, MA, USA: MIT Press, 2018.

23 Torrealba F \& Carrasco MA. A review on electron microscopy and neurotransmitter systems. Brain Research Revoews 200447 5-17. (https://doi.org/10.1016/j.brainresrev.2004.06.004)

24 Morris JF \& Pow DV. Widespread release of peptides in the central nervous system: quantitation of tannic acid-captured exocytoses. Anatomical Record 1991231 437-445. (https://doi.org/10.1002/ ar.1092310406)

25 Morris JF, Christian H, Ma D \& Wang H. Dendritic secretion of peptides from hypothalamic magnocellular neurosecretory neurones: a local dynamic control system and its functions. Experimental Physiology 200085 131S-138S. (https://doi.org/10.1111/j.1469445X.2000.tb00016.x)

26 Pow DV \& Morris JF. Dendrites of hypothalamic magnocellular neurons release neurohypophysial peptides by exocytosis. Neuroscience 198932 435-439. (https://doi.org/10.1016/03064522(89)90091-2)

27 Del-Bel E \& De-Miguel FF. Extrasynaptic neurotransmission mediated by exocytosis and diffusive release of transmitter substances. Frontiers in Synaptic Neuroscience 201810 13. (https://doi.org/10.3389/ fnsyn.2018.00013)

28 De-Miguel FF \& Nicholls JG. Release of chemical transmitters from cell bodies and dendrites of nerve cells. Philosophical Transactions of the Royal Society of London: Series B, Biological Sciences $2015 \mathbf{3 7 0}$ 20140181. (https://doi.org/10.1098/rstb.2014.0181)

29 Brown CH, Bains JS, Ludwig M \& Stern JE. Physiological regulation of magnocellular neurosecretory cell activity: integration of intrinsic, local and afferent mechanisms. Journal of Neuroendocrinology 201325 678-710. (https://doi.org/10.1111/jne.12051)

30 Stern JE. Neuroendocrine-autonomic integration in the paraventricular nucleus: novel roles for dendritically released neuropeptides. Journal of Neuroendocrinology 201527 487-497. (https://doi.org/10.1111/jne.12252)

31 Ludwig M, Apps D, Menzies J, Patel JC \& Rice ME. Dendritic release of neurotransmitters. Comprehensive Physiology 20167 235-252. (https://doi.org/10.1002/cphy.c160007)

32 Steuer Costa W, Yu SC, Liewald JF, \& Gottschalk A. Fast cAMP modulation of neurotransmission via neuropeptide signals and vesicle loading. Current Biology 201727 495-507. (https://doi. org/10.1016/j.cub.2016.12.055)

33 Morris JF. Hormone storage in individual neurosecretory granules of the pituitary gland: a quantitative ultrastructural approach to 
hormone storage in the neural lobe. Journal of Endocrinology $1976 \mathbf{6 8}$ 209-224. (https://doi.org/10.1677/joe.0.0680209)

34 Nordmann JJ \& Morris JF. Method for quantitating the molecular content of a subcellular organelle: hormone and neurophysin content of newly formed and aged neurosecretory granules. PNAS 198481 180-184. (https://doi.org/10.1073/pnas.81.1.180)

35 Morris JF. Distribution of neurosecretory granules among the anatomical compartments of the neurosecretory processes of the pituitary gland: a quantitative ultrastructural approach to hormone storage in the neural lobe. Journal of Endocrinology $197668225-234$ (https://doi.org/10.1677/joe.0.0680225)

36 Leng G \& Ludwig M. Neurotransmitters and peptides: whispered secrets and public announcements. Journal of Physiology $2008 \mathbf{5 8 6}$ 5625-5632. (https://doi.org/10.1113/jphysiol.2008.159103)

37 Maicas-Royo J, Leng G \& MacGregor DJ. A predictive, quantitative model of spiking activity and stimulus-secretion coupling in oxytocin neurons. Endocrinology 20183 1433-1452. (https://doi. org/10.1210/en.2017-03068)

38 Ludwig M \& Leng G. Dendritic peptide release and peptidedependent behaviours. Nature Reviews Neuroscience 20067 126-136. (https://doi.org/10.1038/nrn1845)

39 Ludwig M, Sabatier N, Bull PM, Landgraf R, Dayanithi G \& Leng G. Intracellular calcium stores regulate activity-dependent neuropeptide release from dendrites. Nature 2002418 85-89. (https://doi. org/10.1038/nature00822)

40 Sabatier N, Caquineau C, Dayanithi G, Bull P, Douglas AJ, Guan XM, Jiang M, Van der Ploeg L \& Leng G. Alpha-melanocytestimulating hormone stimulates oxytocin release from the dendrites of hypothalamic neurons while inhibiting oxytocin release from their terminals in the neurohypophysis. Journal of Neuroscience 200323 10351-10358. (https://doi.org/10.1523/ JNEUROSCI.23-32-10351.2003)

41 Tobin V, Leng G \& Ludwig M. The involvement of actin, calcium channels and exocytosis proteins in somato-dendritic oxytocin and vasopressin release. Frontiers in Physiology 20123 261. (https://doi. org/10.3389/fphys.2012.00261)

42 Rossoni E, Feng J, Tirozzi B, Brown D, Leng G \& Moos F. Emergent synchronous bursting of oxytocin neuronal network. PLoS Computational Biology 20084 e1000123. (https://doi.org/10.1371/ journal.pcbi.1000123)

43 Herkenham M. Mismatches between neurotransmitter and receptor localizations in brain: observations and implications. Neuroscience 198723 1-38. (https://doi.org/10.1016/0306-4522(87)90268-5)

44 Zupanc GK. Peptidergic transmission: from morphological correlates to functional implications. Micron 199627 35-91. (https://doi. org/10.1016/0968-4328(95)00028-3)

45 Knobloch HS, Charlet A, Hoffmann LC, Eliava M, Khrulev S, Cetin AH, Osten P, Schwarz MK, Seeburg PH, Stoop R, et al. Evoked axonal oxytocin release in the central amygdala attenuates fear response. Neuron 201273 553-566. (https://doi.org/10.1016/j. neuron.2011.11.030)

46 Chini B, Verhage M \& Grinevich V. The action radius of oxytocin release in the mammalian CNS: from single vesicles to behavior. Trends in Pharmacological Sciences 201738 982-991. (https://doi. org/10.1016/j.tips.2017.08.005)

47 Ponzio TA, Ni Y, Montana V, Parpura V \& Hatton GI. Vesicular glutamate transporter expression in supraoptic neurones suggests a glutamatergic phenotype. Journal of Neuroendocrinology $2006 \mathbf{1 8}$ 253-265. (https://doi.org/10.1111/j.1365-2826.2006.01410.x)

48 Grinevich V, Knobloch-Bollmann HS, Eliava M, Busnelli M \& Chini B. Assembling the puzzle: pathways of oxytocin signaling in the brain. Biological Psychiatry 201679 155-164. (https://doi. org/10.1016/j.biopsych.2015.04.013)

49 van den Pol AN. Neuropeptide transmission in brain circuits. Neuron 201276 98-115. (https://doi.org/10.1016/j.neuron.2012.09.014)
50 Silver R., LeSauter J, Tresco PA \& Lehman MN. A diffusible coupling signal from the transplanted suprachiasmatic nucleus controlling circadian locomotor rhythms. Nature 1996382 810-813. (https://doi. org/10.1038/382810a0)

51 Stamatiades GA \& Kaiser UB. Gonadotropin regulation by pulsatile GnRH: signaling and gene expression. Molecular and Cellular Endocrinology 2018463 131-141. (https://doi.org/10.1016/j. mce.2017.10.015)

52 Melamed P, Haj M, Yosefzon Y, Rudnizky S, Wijeweera A, Pnueli L \& Kaplan A. Multifaceted targeting of the chromatin mediates gonadotropin-releasing hormone effects on gene expression in the gonadotrope. Frontiers in Endocrinology 20189 58. (https://doi. org/10.3389/fendo.2018.00058)

53 Nakajima Y, Yamada M, Taguchi R, Shibusawa N, Ozawa A, Tomaru T, Hashimoto K, Saito T, Tsuchiya T, Okada S, et al. NR4A1 (Nur77) mediates thyrotropin-releasing hormone-induced stimulation of transcription of the thyrotropin beta gene: analysis of TRH knockout mice. PLOS ONE 20127 e40437. (https://doi.org/10.1371/journal. pone.0040437)

54 Mayo KE, Miller T, DeAlmeida V, Godfrey P, Zheng J \& Cunha SR. Regulation of the pituitary somatotroph cell by GHRH and its receptor. Recent Progress in Hormone Research 200055 237-266.

55 Smith CB \& Eiden LE. Is PACAP the major neurotransmitter for stress transduction at the adrenomedullary synapse? Journal of Molecular Neuroscience 201248 403-412. (https://doi.org/10.1007/s12031-0129749-x)

56 Owman C. Peptidergic vasodilator nerves in the peripheral circulation and in the vascular beds of the heart and brain. Blood Vessels 199027 73-93.

57 Oliet SH \& Bonfardin VD. Morphological plasticity of the rat supraoptic nucleus - cellular consequences. European Journal of Neuroscience 201032 1989-1994. (https://doi.org/10.1111/j.14609568.2010.07514.x)

58 Dhar M, Wayman GA, Zhu M, Lambert TJ, Davare MA \& Appleyard SM. Leptin-induced spine formation requires TrpC channels and the CaM kinase cascade in the hippocampus. Journal of Neuroscience 201434 10022-10033. (https://doi.org/10.1523/ JNEUROSCI.2868-13.2014)

59 Dhar M, Zhu M, Impey S, Lambert TJ, Bland T, Karatsoreos IN, Nakazawa T, Appleyard SM \& Wayman GA. Leptin induces hippocampal synaptogenesis via CREB-regulated microRNA-132 suppression of p250GAP. Molecular Endocrinology 201428 1073-1087. (https://doi.org/10.1210/me.2013-1332)

60 Garcia I, Quast KB, Huang L, Herman AM, Selever J, Deussing JM, Justice NJ \& Arenkiel BR. Local CRH signaling promotes synaptogenesis and circuit integration of adult-born neurons. Developmental Cell 201430 645-659. (https://doi.org/10.1016/j. devcel.2014.07.001)

61 Herman JP \& Tasker JG. Paraventricular hypothalamic mechanisms of chronic stress adaptation. Frontiers in Endocrinology 20167137.

62 Grattan DR. 60 YEARS OF NEUROENDOCRINOLOGY: The hypothalamo-prolactin axis. Journal of Endocrinology 2015226 T101-T122. (https://doi.org/10.1530/JOE-15-0213)

63 Russell JA, Leng G \& Douglas AJ. The magnocellular oxytocin system, the fount of maternity: adaptations in pregnancy. Frontiers in Neuroendocrinology 200324 27-61. (https://doi.org/10.1016/S00913022(02)00104-8)

64 Arrowsmith S \& Wray S. Oxytocin: its mechanism of action and receptor signalling in the myometrium. Journal of Neuroendocrinology 201426 356-369. (https://doi.org/10.1111/jne.12154)

65 Leng G \& Sabatier N. Measuring oxytocin and vasopressin: bioassays, immunoassays and random numbers. Journal of Neuroendocrinology 201628 [epub]. (https://doi.org/10.1111/jne.12413)

66 Johnson ZV, Walum H, Xiao Y, Riefkohl PC, \& Young LJ. Oxytocin receptors modulate a social salience neural network in male https://ec.bioscientifica.com

https://doi.org/10.1530/EC-18-0367 (c) 2018 The authors

Published by Bioscientifica Ltd

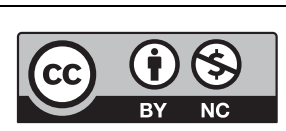

This work is licensed under a Creative Commons Attribution-NonCommercial 4.0 International License. 
prairie voles. Hormones and Behavior 201787 16-24. (https://doi. org/10.1016/j.yhbeh.2016.10.009)

67 Johnson ZV \& Young LJ. Oxytocin and vasopressin neural networks: Implications for social behavioral diversity and translational neuroscience. Neuroscience and Biobehavioral Reviews 2017 76 87-98. (https://doi.org/10.1016/j.neubiorev.2017.01.034)

68 Bicknell RJ. Optimizing release from peptide hormone secretory nerve terminals. Journal of Experimental Biology 1988139 51-65.

69 MacGregor DJ \& Leng G. Spike triggered hormone secretion in vasopressin cells; a model investigation of mechanism and heterogeneous population function. PLoS Computational Biology 2013 9 e1003187. (https://doi.org/10.1371/journal.pcbi.1003187)

70 Higuchi T, Bicknell RJ \& Leng G. Reduced oxytocin release from the neural lobe of lactating rats is associated with reduced pituitary content and does not reflect reduced excitability of oxytocin neurons. Journal of Neuroendocrinology 19913 297-302. (https://doi. org/10.1111/j.1365-2826.1991.tb00278.x)

71 Kalwat MA \& Cobb MH. Mechanisms of the amplifying pathway of insulin secretion in the beta cell. Pharmacology and Therapeutics 2017 179 17-30. (https://doi.org/10.1016/j.pharmthera.2017.05.003)

72 Seino S, Takahashi H, Fujimoto W \& Shibasaki T. Roles of cAMP signalling in insulin granule exocytosis. Diabetes Obesity and Metabolism 200911 (Supplement 4) 180-188. (https://doi. org/10.1111/j.1463-1326.2009.01108.x)

73 Brown $\mathrm{CH} \&$ Bourque CW. Mechanisms of rhythmogenesis: insights from hypothalamic vasopressin neurons. Trends in Neuroscience 2006 29 108-115. (https://doi.org/10.1016/j.tins.2005.11.005)

74 Leng G, Brown C, Sabatier N \& Scott V. Population dynamics in vasopressin cells. Neuroendocrinology 200888 160-172. (https://doi. org/10.1159/000149827)

75 Tobin VA, Arechaga G, Brunton PJ, Russell JA, Leng G, Ludwig M \& Douglas AJ. Oxytocinase in the female rat hypothalamus: a novel mechanism controlling oxytocin neurones during lactation. Journal of Neuroendocrinology 201426 205-216. (https://doi.org/10.1111/ jne.12141)

76 Diao F, Elliott AD, Diao F, Shah S, \& White BH. Neuromodulatory connectivity defines the structure of a behavioral neural network. eLife 20176 e29797. (https://doi.org/10.7554/eLife.29797)

77 Bargmann CI. Beyond the connectome: how neuromodulators shape neural circuits. Bioessays 201234 458-465. (https://doi.org/10.1002/ bies.201100185)

78 Elphick MR, Mirabeau O \& Larhammar D. Evolution of neuropeptide signalling systems. Journal of Experimental Biology 2018221 jeb151092. (https://doi.org/10.1242/jeb.151092)

79 Jekely G, Melzer S, Beets I, Kadow ICG, Koene J, Haddad S \& HoldenDye $L$. The long and the short of it - a perspective on peptidergic regulation of circuits and behaviour. Journal of Experimental Biology 2018221 jeb166710. (https://doi.org/10.1242/jeb.166710)

80 Tessmar-Raible K, Raible F, Christodoulou F, Guy K, Rembold M, Hausen H \& Arendt D. Conserved sensory-neurosecretory cell types in annelid and fish forebrain: insights into hypothalamus evolution. Cell 2007129 1389-1400. (https://doi.org/10.1016/j. cell.2007.04.041)

81 Tang SC, Baeyens L, Shen CN, Peng SJ, Chien HJ, Scheel DW, Chamberlain CE \& German MS. Human pancreatic neuro-insular network in health and fatty infiltration. Diabetologia 201861 168-181. (https://doi.org/10.1007/s00125-017-4409-x)

82 Holz GG, Chepurny OG \& Leech CA. Leptin-stimulated KATP channel trafficking: a new paradigm for beta-cell stimulus-secretion coupling? Islets 20135 229-232. (https://doi.org/10.4161/isl.26958)
83 Kiehn JT, Tsang AH, Heyde I, Leinweber B, Kolbe I, Leliavski A \& Oster H. Circadian rhythms in adipose tissue physiology. Comprehensive Physiology 20177 383-427. (https://doi.org/10.1002/ cphy.c160017)

84 Abu Bakar H, Robert Dunn W, Daly C \& Ralevic V. Sensory innervation of perivascular adipose tissue: a crucial role in artery vasodilatation and leptin release. Cardiovascular Research $2017 \mathbf{1 1 3}$ 962-972. (https://doi.org/10.1093/cvr/cvx062)

85 Caron A, Lee S, Elmquist JK \& Gautron L. Leptin and brain-adipose crosstalks. Nature Reviews Neuroscience 201819 153-165. (https://doi. org/10.1038/nrn.2018.7)

86 Pan W, Adams JM, Allison MB, Patterson C, Flak JN, Jones J, Strohbehn G, Trevaskis J, Rhodes CJ, Olson DP \& Myers MG. Essential role for hypothalamic calcitonin receptor-expressing neurons in the control of food intake by leptin. Endocrinology 2018 159 1860-1872. (https://doi.org/10.1210/en.2017-03259)

87 Leinninger GM, Opland DM, Jo YH, Faouzi M, Christensen L, Cappellucci LA, Rhodes CJ, Gnegy ME, Becker JB, Potho EN et al. Leptin action via neurotensin neurons controls orexin, the mesolimbic dopamine system and energy balance. Cell Metabolism 201114 313-323. (https://doi.org/10.1016/j.cmet.2011.06.016)

88 Pandit R, Beerens S, \& Adan RAH. Role of leptin in energy expenditure: the hypothalamic perspective. American Journal of Physiology 2017312 R938-R947. (https://doi.org/10.1152/ ajpregu.00045.2016)

$89 \mathrm{Xu}$ L. Leptin action in the midbrain: from reward to stress. Journal of Chemical Neuroanatomy 2014 61-62 256-265. (https://doi. org/10.1016/j.jchemneu.2014.06.007)

90 Domingos AI, Vaynshteyn J, Voss HU, Ren X, Gradinaru V, Zang F, Deisseroth K, de Araujo IE \& Friedman J. Leptin regulates the reward value of nutrient. Nature Neuroscience 201114 1562-1568. (https:// doi.org/10.1038/nn.2977)

91 McClintock B. The significance of responses of the genome to challenge. Science 1984226 792-801. (https://doi.org/10.1126/ science.15739260)

92 Al-Hasani R, Wong JT, Mabrouk OS, McCall JG, Schmitz GP, PorterStransky KA, Aragona BJ, Kennedy RT \& Bruchas MR. In vivo detection of optically-evoked opioid peptide release. eLife 20187 e36520. (https://doi.org/10.7554/eLife.36520)

93 Sun F, Zeng J, Jing M, Zhou J, Feng J, Owen SF, Luo Y, Li F, Wang H, Yamaguchi T, et al. A genetically encoded fluorescent sensor enables rapid and specific detection of dopamine in flies, fish, and mice. Cell 2018174 481.e19-496.e19. (https://doi.org/10.1016/j. cell.2018.06.042)

94 Jing M, Zhang P, Wang G, Feng J, Mesik L, Zeng J, Jiang H, Wang S, Looby JC, Guagliardo NA, et al. A genetically encoded fluorescent acetylcholine indicator for in vitro and in vivo studies. Nature Biotechnology 201836 726-737. (https://doi.org/10.1038/nbt.4184)

95 Wang H, Jing M \& Li Y. Lighting up the brain: genetically encoded fluorescent sensors for imaging neurotransmitters and neuromodulators. Current Opinion in Neurobiology 201850 171-178. (https://doi.org/10.1016/j.conb.2018.03.010)

96 Bendesky A, Kwon YM, Lassance JM, Lewarch CL, Yao S, Peterson BK, He MX, Dulac C \& Hoekstra HE. The genetic basis of parental care evolution in monogamous mice. Nature 2017544 434-439. (https:// doi.org/10.1038/nature22074)

97 Jiang J, Cui H \& Rahmouni K. Optogenetics and pharmacogenetics: principles and applications. American Journal of Physiology 2017313 R633-R645. (https://doi.org/10.1152/ajpregu.00091.2017)

Received in final form 19 September 2018

Accepted 28 September 2018

Accepted Preprint published online 4 October 2018 https://ec.bioscientifica.com https://doi.org/10.1530/EC-18-0367 (c) 2018 The authors Published by Bioscientifica Ltd
This work is licensed under a Creative Commons Attribution-NonCommercial 4.0 International License. 